\title{
Preparing and Evaluation of New Nutritious Products from Quail Meat
}

\author{
Manar M. Farag1, Nadia A. Abd-El-Aziz ${ }^{2 *}$, Afaf M. Ali1 \\ ${ }^{1}$ Meat and Fish Technology Research Department, Food Technology Research Institute, Agriculture Research Center, Cairo, Egypt \\ ${ }^{2}$ Meat and Fish Technology Research Department, Food Technology Research Institute, Agriculture Research Center, Alexandria, \\ Egypt \\ Email: *dr.nadiaahmed@yahoo.com
}

How to cite this paper: Farag, M.M., Abd-El-Aziz, N.A. and Ali, A.M. (2021) Preparing and Evaluation of New Nutritious Products from Quail Meat. Food and Nutrition Sciences, 12, 889-898.

https://doi.org/10.4236/fns.2021.129066

Received: August 26, 2021

Accepted: September 12, 2021

Published: September 15, 2021

Copyright (C) 2021 by author(s) and Scientific Research Publishing Inc. This work is licensed under the Creative Commons Attribution International License (CC BY 4.0).

http://creativecommons.org/licenses/by/4.0/

\begin{abstract}
The objective of this study is preparation of new nutritious products from quail meat compared to other products prepared from chicken meat as control and commercial products which bought from supermarket. The proximate composition, chemical, physical and sensorial properties were evaluated. The different products were prepared as sausage form quail meat (SQ), chicken meat (SC) and commercial (SCo), and, kofta from quail meat $(\mathrm{KQ})$, chicken meat $(\mathrm{KC})$ and commercial $(\mathrm{KCo})$, and, nuggets from quail meat (NQ), chicken meat (NC) and commercial (NCo). The result observed that the chemical composition of products that prepared from quail meat recorded the highest content of protein and ash, on contrary, the lowest content of fat compared with products that prepare from chicken meat as control or commercial. All products that prepared from quail meat recorded high content of $\mathrm{K}, \mathrm{Ca}, \mathrm{Mg}, \mathrm{P}, \mathrm{Fe}, \mathrm{Zn}$, Se and vitamin A, Kofta was the highest one followed by nuggets then sausage products. While sausage products that prepared from both quail and chicken meat as control recorded the highest content of vitamin E, followed nuggets and kofta, respectively compared with commercial products. The results indicated decreasing cooking loss after preparing of quail meat products followed by both chicken meat products as control and commercial product, increasing water capacity (WHC) of KQ and plasticity of SQ and NQ. All products were accepted from panelists while slightly significant difference among these products $(\mathrm{P}>0.05)$. SC was the highest score in colour, taste, odour, texture and overall acceptability compared with SQ and SCo. Generally products were prepared from quail meat which showed high acceptance in sensory evaluation by panelists.
\end{abstract}

\section{Keywords}

Quail Meat, Chicken Meat, Sausage, Kofta, Nuggets Products, Minerals, Vitamins, Nutritious 


\section{Introduction}

The common commercial quail (Coturnix coturnix japonica) is a tiny bird, with a flavored meat suitable for both quick and slow cooking, being appreciated as a delicatessen by consumers. Quail meat has a very significant position in the global poultry industry [1]. Quail provides more advantages than the chicken such as its resistance to many poultry diseases that afflict chickens, its greater capacity to benefit from food, high reproduction proportions, and also low feed intake [2]. Quail meat is recommended for the low fat diet because it contains low amount of fat and cholesterol especially thanks to its thin skin and low fat accumulation between its tissues [3]. It is an ideal food for all ages due to its high meat yield, less shrinkage during cooking, being more effort less to cook, and being easier to serve [4].

The consumption of bird meat as quail has gained increasing favour among consumers, who appreciate its texture and flavour as well as the low fat and cholesterol content [5].

Poultry meat and their products are consumed in large quantities and the consumption is growing all over the world [6]. Quail products have gained popularity in the last few years by consumers. Quail meat is recommended for the low-fat diet because it contains low amount of fat and cholesterol especially thanks to its thin skin and low fat accumulation between its tissues [3]. Japanese quail meat may be taken into consideration in diet for prevention of heart diseases because of high C18:1 content. The ratio between PUFAs and SFAs was 0.43 in female quail meat and 0.40 in male quail meat. Both ratios are in accordance with the WHO recommendations. Quail meatballs and pickled quail eggs are an acceptable market product, have a very interesting chemical composition. Quail meatballs have high concentration of protein content, lower carbohydrate content and high minerals content. Sum of essential amino acids in quail meatballs was $6.17 \mathrm{~g} / 100 \mathrm{~g}$ sample. This value equals $47.5 \%$ from protein [7]. According to [8] quail meat can be used for the manufacture of meatballs successfully by using as an alternative to the use of other meats such as beef and chicken. Quails are valuable for the high nutritional content of both their eggs and meat [9].

The European quail strain (Coturnix coturnix) is used predominantly for meat production [10]. According to [11], quail meat production has been growing and gaining popularity in recent years due mainly to a search for new sources of quality animal protein. The use of quail meat, although still limited, is increasing because of the introduction of a European variety that meets the requirements of meat production. Currently, functional quail meat food products are sold on the market, which is the basis for the production of original products with high quality and nutritional value indicators. Quail meat had high organoleptic characteristics: juiciness, aroma, taste, delicate consistence. It is rich in macro- and microelements, such as iron, phosphorus, calcium, sodium [12] [13].

The demand for restructured meat products, such as nuggets, has increased 
significantly in the last 20 years [14]. This process offers many opportunities to the food industry [15].

Therefore, the aim of this study was to utilize the quail meat in preparation new healthy and economic products rich in protein, minerals and vitamins such as sausage, kofta and nuggets. The proximate compositions, physical and sensorial properties of these products were evaluated after preparation.

\section{Materials and Methods}

\subsection{Materials}

Skinless fresh quail meat was purchased from outlets of the Ministry of Agriculture in Giza, Egypt. Whole fresh skinless chicken $\sim 1.5 \mathrm{~kg}$, hunk preserved in salt (intestines of sheep), fresh onion, garlic, parsley, corn starch, wheat flour, fresh whole eggs, refined fine iodized common salt, fresh concentrated tomato juice, dried full cream cow milk and sunflower oil of Crystal, Co., virgin extra olive oil with $0.5 \%$ acidity, Borges, Co., spices mixtures, (chickpea and bulgur) of El Doha, Co., grease-proof paper, polyethylene bags, foam plates $(22 \times 17 \mathrm{~cm})$, (commercial sausage, commercial kofta) from welad Ragab mole and commercial nuggets of (watania Co.) were purchased from Cairo local market, all reagents and chemicals used in this study were analytical grades.

\subsection{Methods}

\subsubsection{Technological Methods}

Preparation of quail meat: Quail washed well, and cooked in boiling water for $\sim 15 \mathrm{~min}$, cooled to room temperature then separate meat.

Preparation of chicken meat: Whole fresh skinless chicken washed well and separated bones from chicken meat specially breast meat and thighs meat.

Preparation of sausage: Deboned skinless quail meat was minced 2 times through $5 \mathrm{~mm}$ plate of Luska meat chopper and mixed with (olive oil and ice water were added as emulsion), then other ingredients such as; minced garlic, ground chickpea, ground bulgur, concentrated tomato juice, salt and spices mixtures were hand mixed for $5 \mathrm{~min}$. Sausage batter was stuffed into $25-\mathrm{mm}$ natural casing (hunk of sheep) to produce approximately 35 -g sausage links. The sausage links were placed in a single layer in foam plate. Tow formulation were prepared sausage from quail meat (SQ) and sausage from chicken meat as a control (SC). All samples kept at $-18^{\circ} \mathrm{C}$ until use.

Preparation of kofta product: Minced meat was mixed with chopped fresh onion, chopped fresh garlic, parsley, salt, spices mixture and dried full cream cow milk. Tow formulation were prepared kofta product from quail meat (KQ) kofta product from chicken meat (KC) as control. Each formula was well mixed, shaped into kofta with approximately $30 \mathrm{~g}$. weight then placed on a foam plate, packed inside poly ethylene bags, stored at $-18^{\circ} \mathrm{C}$ until use.

Preparation of nuggets: Minced meat was mixed with minced fresh onion, minced garlic, corn starch, salt, ground chickpea, ground bulgur, spices mixture, 
dried full cream cow milk, olive oil and ice water. Two formulations of nuggets were prepared quail nuggets (NQ) and chicken nuggets (NC) as control. Nuggets were coated using the following Ingredients for covering pieces of nuggets $(5 \%$ Egg $+5 \mathrm{ml} \mathrm{milk}+2 \%$ corn starch $+2 \%$ wheat flour $+1 \%$ salt and spices mixture) The coated nuggets kept at $4^{\circ} \mathrm{C}$ for at least 45 minutes before frying, nuggets product kept at $-18^{\circ} \mathrm{C}$ until use.

\section{Cooking of products:}

Sausage product was cooked by boiling at $100^{\circ} \mathrm{C}$ for $\sim 15 \mathrm{~min}$., kofta product was cooked by steam $\sim 20 \mathrm{~min}$. while nuggets product was cooked by deep frying for $\sim 4 \mathrm{~min}$. All samples of sausage, kofta and nuggets were analyzed comparing with commercial product (Table 1).

\subsubsection{Analytical Methods}

1) Chemical analysis

a) Proximate composition: Moisture, protein, fat and ash contents were evaluated according to [16] Carbohydrate was calculated by difference.

b) Minerals determination: $\mathrm{K}, \mathrm{Na}, \mathrm{Ca}, \mathrm{Mg}, \mathrm{P}, \mathrm{Fe}, \mathrm{Zn}$ and Se were determined using inductively coupled plasma atomic emission spectroscopy (ICP-OES) according to standard method US EPA Meth d 200.7 and US EPA Method 6010 C.

c) Vitamins: Vitamin A and E were determined by HPLC System Controller (SCL-6A) using a Shimadzu CTO 6-A column supplies with a SPD-6AV detector (Japan), under high-pressure solvent delivery unit (LC-20AD) according to [16].

A sample volume of $20 \mu \mathrm{l}$ was run at a flow rate of $2 \mathrm{ml} / \mathrm{min}$ for $15 \mathrm{~min}$ at $20^{\circ} \mathrm{C}$. Vitamin A and vitamin $\mathrm{E}$ were identified and quantified by comparing their retention times to known previously injected standards

2) Physical properties

a) Cooking loss: all products was determined and calculated as described by [17].

$\%$ cooking loss $=$ sample weight before cooking - sample weight after cooking/sample weight before cooking $\times 100$.

$\%$ cooking yield $=100-\%$ cooking loss

b) Water holding capacity and plasticity $\left(\mathrm{cm}^{2} / 0.3 \mathrm{~g}\right)$ were determined by using filter-press method described by [18].

Hence, bound water \% of moisture content was calculated as follows:

$$
\% \text { Bound water }=\frac{\text { Moisture }-\frac{\mathrm{Cm}^{2} \times 100 \times 8.4}{0.3 \times 1000}}{\text { Moisture }} \times 100
$$

where; $\mathrm{Cm}^{2}$ area resembling WHC in $\mathrm{cm}^{2}, 8.4=\mathrm{mg}$ free water/each $1 \mathrm{~cm}^{2}$ of WHC. 0.3 = Sample weight.

\section{c) Texture Coefficient (indices):}

Protein water coefficient (PWC) and protein water fat coefficient (PWFC) were calculated according to the methods described by [19]. The less obtained value at PWC and PWFC, the more tenderness (The less texture) and vice versa.

$\mathrm{PWC}=\%$ protein $/ \%$ moisture $\mathrm{PWFC}=\%$ protein $/ \%$ moisture $+\%$ fat 
Table 1. Ingredient content of sausage, kofta product and nuggets.

\begin{tabular}{cccc}
\hline Ingredient (\%) & Sausage & Kofta product & Nuggets \\
\hline Minced meat (quail meat or chicken meat) & 60 & 85 & 60 \\
Onion & ----- & 6.0 & 4.0 \\
Garlic & 1.0 & 3.0 & 1.0 \\
Ground chickpea & 2.0 & ----- & 2.0 \\
Ground bulgur & 2.0 & ---- & 2.0 \\
Corn starch & ----- & & 2.0 \\
Salt & 1.5 & 1.5 & 1.0 \\
Spices mixture & 1.5 & 1.5 & 1.0 \\
Olive oil & 15 & ---- & 5.0 \\
Ice water & 15 & ---- & 5.0 \\
Parsley & --- & 1.0 & --- \\
dried full cream cow milk & ---- & 2.0 & 2.0 \\
Concentrate tomato juice & 2.0 & --- & --- \\
Coating material & ---- & --- & 15.0 \\
\hline
\end{tabular}

\subsubsection{Sensory Evaluation}

Colour, taste, odour texture, and overall acceptability of cooked sausage, kofta and nuggets products were organoleptically evaluated using 10 trained panelists from Meat and Fish Technology Research Department, Food Technology Research Institute, Agriculture Research Center, Cairo, Egypt. According to nine point scale, as described by [20] by Judging scale for each factor was as follows: Very good (8 - 9), Good (6 - 7), Fair (4 - 5), Poor (2 - 3), Very poor (0 - 1).

\subsubsection{Statistical Analysis}

Data was statistically analyzed using Statistical Package for Social Sciences (SPSS) software version 22. The level of significant difference was determined at $\mathrm{P} \leq 0.05$. Mean \pm Standard Deviation (SD) of mean was used.

\section{Results and Discussion}

\subsection{Chemical Composition}

Data are shown in Table 2 slightly decrease in moisture after cooking attributed to cooking method boiling or by steam. Results observed the protein, ash and fat content ranged from (12.11 - 20.22), (2.50 - 4.32) and (2.50 - 18.05)\% respectively, before cooking, whereas, after cooking, the products content of protein and ash increased to ranged from (12. $80-22.10)$ and $(2.83-4.83) \%$, respectively, Increasing in protein and ash content related to decrease of moisture content after cooking. While products content of fat decreased by cooking to ranged from (2.05 to 15.32)\%. This reduction in fat content as result of cooking by boiling or steam that due to losses fat content in sausage and kofta product but fat content increased in nuggets as results of deep frying. So that used quail meat with low fat content leads to produce healthy product. The previous data agree 
Table 2. Chemical composition of sausage, kofta and nuggets products before and after cooking (g/100g) on wet weight basis.

\begin{tabular}{cccccccccccc}
\hline $\begin{array}{c}\text { Chemical } \\
\text { composition }\end{array}$ & \multicolumn{2}{c}{ Moisture } & \multicolumn{2}{c}{ Protein } & \multicolumn{2}{c}{ Ash } & & Fat & & Carbohydrates \\
\hline Products: & $\begin{array}{c}\text { Before } \\
\text { cooking }\end{array}$ & $\begin{array}{c}\text { After } \\
\text { cooking }\end{array}$ & $\begin{array}{c}\text { Before } \\
\text { cooking }\end{array}$ & $\begin{array}{c}\text { After } \\
\text { cooking }\end{array}$ & $\begin{array}{c}\text { Before } \\
\text { cooking }\end{array}$ & $\begin{array}{c}\text { After } \\
\text { cooking }\end{array}$ & $\begin{array}{c}\text { Before } \\
\text { cooking }\end{array}$ & $\begin{array}{c}\text { After } \\
\text { cooking }\end{array}$ & $\begin{array}{c}\text { Before } \\
\text { cooking }\end{array}$ & $\begin{array}{c}\text { After } \\
\text { cooking }\end{array}$ \\
\hline Sausages: & & & & & & & & & & \\
SQ & 60.32 & 58.12 & 14.30 & 15.52 & 3.14 & 3.84 & 12.22 & 10.59 & 10.52 & 11.93 \\
SC & 62.22 & 60.50 & 12.80 & 13.60 & 2.54 & 2.95 & 14.30 & 11.90 & 5.28 & 11.05 \\
SCO & 62.90 & 59.52 & 12.11 & 12.80 & 2.50 & 2.83 & 18.05 & 15.32 & 4.44 & 9.53 \\
Kofta: & & & & & & & & & & \\
KQ & 65.42 & 63.11 & 20.22 & 22.10 & 4.32 & 4.83 & 2.50 & 2.05 & 7.54 & 8.91 \\
KC & 72.51 & 63.52 & 17.64 & 19.71 & 3.14 & 3.63 & 3.52 & 3.17 & 3.19 & 9.97 \\
KCO & 67.82 & 63.95 & 13.84 & 16.24 & 2.66 & 3.19 & 12.21 & 8.44 & 3.47 & 8.18 \\
Nuggets: & & & & & & & & & & 19 \\
NQ & 58.91 & 58.27 & 15.71 & 16.30 & 3.57 & 3.91 & 2.51 & 3.89 & 19.31 & 17.63 \\
NC & 63.55 & 60.63 & 13.22 & 14.75 & 3.14 & 3.52 & 3.52 & 4.92 & 16.57 & 16.18 \\
NCO & 61.27 & 60.12 & 12.12 & 12.95 & 2.74 & 2.91 & 8.02 & 12.03 & 15.85 & 11.99 \\
\hline
\end{tabular}

SQ---->> sausage from quail meat, SC-----> sausage from chicken meat as control, SC-----> sausage commercial. KQ-----> kofta from quail meat Kofta from chicken meat as control, KC-----> kofta commercial. NQ------> nuggets from quail meat, NC-----> nuggets from chicken meat as control, NC-----> nuggets commercial.

with [21] who resulted that all quail meat samples had an optimal ratio of protein, ash and fat, the protein content was of carcass groups ranged from 21.67 22.10, whereas, both ash and fat ranged from 1.01 to 1.24 and fat ranged from $3.93 \%$ to $4.15 \%$, respectively.

Generally, the products prepared from quail meat have the highest protein and ash content ranged from (15.52 to 22.10) and from (3.84 to 4.83 )\% for sausage and kofta respectively. That refer to kofta contains more meat reach to $85 \%$ compared both sausage and nuggets which contain $60 \%$ meat only. On the contrary, sausage products have the highest fat content was (12.22 - 18.05) before cooking to $(10.59-15.32) \%$ after cooking for quail meat sausage and chicken meat commercial, respectively.

\section{Mineral and Vitamins Content}

Data in Table 3 showed that using quail meat in preparing sausage, kofta, and nuggets caused a marked rise in its content of $\mathrm{K}, \mathrm{Ca}, \mathrm{Mg}, \mathrm{P}, \mathrm{Fe}, \mathrm{Zn}$, and Se. and results observed that the products that prepared from quail meat have the highest content of minerals except of $\mathrm{Na}$ was low content compared with other products, where products content meat quail followed by the control and commercial products were last one in content minerals where $\mathrm{K}$ ranged from (169 328.6), Ca (9.96 - 44.01), Mg (11.09 - 32.60), P ranged from (132.4 - 336.3), Fe $(0.70$ - 5.54) and $\mathrm{Zn}(0.22-1.90) \mathrm{mg} / 100 \mathrm{~g}$. Both quail meat and control products contain selenium mineral ranged from $(14-20)$ and $(12-15) \mu \mathrm{g} / 100 \mathrm{~g}$, respectively, in same time commercial products were free from selenium. Commercial products showed increasing in Na content compared with other products. In other hand products contented quail meat showed noticeable increase in both vitamin $\mathrm{A}$ and $\mathrm{E}$ than other products, where vitamin $\mathrm{A}$ rises $\sim 13$ times in SQ than SCo (13.19 - 1.32), 3 times in KQ than KCo (63.34 - 23.64) and $\sim 8$ 
Table 3. Minerals (mg/100 g) and vitamins content $(\mu \mathrm{g} / 100 \mathrm{~g})$ of cooked products as wet weight basis.

\begin{tabular}{cccccccccccc}
\hline & \multicolumn{1}{c}{} & \multicolumn{1}{c}{ Minerals (mg/100g) } & & \multicolumn{3}{c}{$\begin{array}{c}\text { Vitamins } \\
(\mu \mathrm{g} / 100 \mathrm{~g})\end{array}$} \\
\cline { 2 - 12 } Products: & $\mathbf{K}$ & $\mathrm{Na}$ & $\mathrm{Ca}$ & $\mathrm{Mg}$ & $\mathrm{P}$ & $\mathrm{Fe}$ & $\mathrm{Zn}$ & $\mathrm{Se}$ & $\mathrm{A}$ & $\mathrm{E}$ \\
\hline Sausages: & & & & & & & & & & \\
SQ & 228 & 33.68 & 20.88 & 25.36 & 238.7 & 4.11 & 1.44 & 14 & 13.19 & 2311 \\
SC & 225 & 51.68 & 17.88 & 22.36 & 148.7 & 1.11 & 0.54 & 12 & 5.69 & 2246 \\
SCO & 169 & 74.11 & 9.96 & 13.67 & 132.4 & 0.70 & 0.31 & - & 1.32 & 109.5 \\
Kofta: & & & & & & & & & & \\
KQ & 328.6 & 45.80 & 44.01 & 32.60 & 336.3 & 5.54 & 1.90 & 20 & 63.34 & 12.0 \\
KC & 312.4 & 71.30 & 39.75 & 28.80 & 208.5 & 1.31 & 0.63 & 17 & 53.14 & 10.9 \\
KCO & 200.5 & 95.77 & 25.33 & 11.09 & 165.0 & 0.72 & 0.22 & - & 23.64 & - \\
Nuggets: & & & & & & & & & & \\
NQ & 270.2 & 42.5 & 46.0 & 31.90 & 267.6 & 4.33 & 1.68 & 18 & 25.71 & 873.2 \\
NC & 263.6 & 60.0 & 43.0 & 28.95 & 181.6 & 1.33 & 0.78 & 15 & 18.21 & 852.9 \\
NCO & 201.9 & 90.2 & 23.8 & 13.43 & 147.3 & 0.90 & 0.43 & - & 3.28 & 593.1 \\
\hline
\end{tabular}

Vitamin D was determined but not detected (below of LOQ = limit of quantification). SQ------) sausage from quail meat, SC------> sausage from chicken meat as control, SCo-----> sausage commercial. KQ------> kofta quail meat Kofta from chicken meat as control, KCo------> kofta commercial. NQ------> nuggets from quail, NC------> nuggets from chicken meat as control, $\mathrm{NCO}=0------>$ nuggets commercial. ${ }^{\star} \mu \mathrm{g} / 100 \mathrm{~g}$.

times in NQ than NCo $(25.71-3.28) \mu \mathrm{g} / 100 \mathrm{~g}$. This mean that quail meat is good source of vitamin A. In the same time quail meat causes increasing in vitamin E content in SQ than SC and SCo, where SQ contented vitamin E as 2311 $\mathrm{mg} / 100 \mathrm{~g}$, while SC contented $2246 \mathrm{mg} / 100 \mathrm{~g}$ and SCo contented $109.5 \mathrm{mg} / 100$. But slightly increase in vitamin $\mathrm{E}$ in both kofta and nuggets products. The previous data agree with [21] who resulted that quail meat content of minerals such as; P, Ca. Na, Fe and vitamin A were 187.1 - 188.2, 23.14 - 23.24, 43.87 - 45.12, $3.12-3.51$ and $0.07 \mathrm{mg} / 100 \mathrm{~g}$ respectively.

\subsection{Physical and Sensorial Properties}

The results in Table 4 indicated cooking loss was low in SQ, KQ and NQ compared with other product. The emulsion property in sausage between fat (olive oil) and water play a major role in decline loss of water. This result agree with [22] who resulted that fat in processed meat products is important due to its contribution to flavor and texture, also exerts considerable influence on binding properties, rheological and structural properties of meat products and in finely comminuted products, such as frankfurters and sausages, fat plays an important role in the formation of a stable meat emulsion [23]. Also, adding ground chickpea and bulgur that binding water. Moreover, it improves their water holding capacity and plasticity. Whereas, nuggets was not contented emulsion property but adding a lot of filling materials like; corn starch, wheat flour, dried full milk beside on crushed chickpea and bulgur improve holding water, while kofta product contains dried full milk and parsley. Results showed increasing in water holding capacity (WHC) and plasticity for commercial product than products contain quail meat or chicken meat.

Form results in Table 4 we found that the commercial products had lowest 
value of protein water coefficient (PWC) and protein water fat coefficient (PWFC) this mean that commercial had texture more tenderness than other prepared products from quail meat and chicken meat.

Sensory properties: Data in Table 5 showed that all products were accepted from panelists while slightly significant difference among these products $(\mathrm{P}>$ 0.05). SC was the highest score in colour, taste, odour, texture and overall acceptability comparing with SQ and SCo. Adding concentrated tomato juice to quail meat sausage may be behind the improving the product color odor, KQ was higher score of most properties than KC and KCo. On other hand NCo showed highest score in all properties. Generally products were prepared from quail meat showed high acceptance in sensory evaluation by panelists.

Table 4. Physical properties of cooked sausage, kofta and nuggets products.

\begin{tabular}{|c|c|c|c|c|c|c|c|}
\hline \multirow{2}{*}{$\begin{array}{l}\text { Properties } \\
\text { Products }\end{array}$} & \multirow{2}{*}{$\begin{array}{c}\text { Cooking } \\
\text { loss } \%\end{array}$} & \multirow{2}{*}{$\begin{array}{l}\text { Cooking } \\
\text { yield \% }\end{array}$} & \multirow{2}{*}{$\begin{array}{c}\text { WHC } \\
\left(\mathrm{cm}^{2} / 0.3 \mathrm{~g}\right)\end{array}$} & \multirow{2}{*}{$\begin{array}{l}\text { Plasticity } \\
\mathrm{Cm}^{2}\end{array}$} & \multirow{2}{*}{$\begin{array}{c}\text { bound } \\
\text { water \% }\end{array}$} & \multicolumn{2}{|c|}{ Texture profile } \\
\hline & & & & & & PWC \% & PWFC \% \\
\hline \multicolumn{8}{|l|}{ Sausages: } \\
\hline SQ & 3.0 & 97.0 & 1.0 & 2.3 & 95.18 & 0.26 & 0.22 \\
\hline SC & 16.0 & 84.0 & 1.0 & 1.3 & 95.37 & 0.22 & 0.18 \\
\hline $\mathrm{SCO}$ & 22.0 & 78.0 & 1.3 & 0. & 93.88 & 0.21 & 0.17 \\
\hline \multicolumn{8}{|l|}{ Kofta: } \\
\hline KQ & 5.0 & 95.0 & 3.5 & 0.3 & 88.47 & 0.35 & 0.33 \\
\hline $\mathrm{KC}$ & 23.0 & 77.0 & 1.3 & 1.1 & 94.26 & 0.31 & 0.28 \\
\hline $\mathrm{KCO}$ & 30.0 & 70.0 & 2.4 & 0.6 & 89. & 0.25 & 0.22 \\
\hline \multicolumn{8}{|l|}{ Nuggets: } \\
\hline NQ & 2.0 & 98.0 & 0.6 & 2.9 & 97.11 & 0.27 & 0.26 \\
\hline NC & 12 & 88.0 & 1.0 & 1.5 & 95.38 & 0.24 & 0.22 \\
\hline NCO & 8.0 & 92.0 & 0.9 & 2.3 & 95.80 & 0.21 & 0.17 \\
\hline
\end{tabular}

SQ----> sausage from quail meat, SC----> sausage from chicken meat as control, SCo----> sausage commercial. KQ---> kofta quail meat Kofta from chicken meat as control, KCo----> kofta commercial. NQ----> nuggets from quail, NC----> nuggets from chicken meat as control, NCo----> nuggets commercial.

Table 5. Sensory properties of cooked products.

\begin{tabular}{cccccc}
\hline Properties & Color & Taste & Odor & Texture & $\begin{array}{c}\text { Overall } \\
\text { acceptaility }\end{array}$ \\
\cline { 1 - 3 } Products & & & & & \\
\cline { 1 - 5 } Sausages: & & & & & \\
SQ & $7.5 \pm 0.84^{\mathrm{c}}$ & $7.6 \pm 1.07^{\mathrm{b}}$ & $7.6 \pm 0.96^{\mathrm{a}}$ & $7.7 \pm 0.82^{\mathrm{a}}$ & $7.9 \pm 0.99^{\mathrm{ab}}$ \\
SC & $8.1 \pm 0.87^{\mathrm{abc}}$ & $8.4 \pm 0.69^{\mathrm{ab}}$ & $7.9 \pm 0.87^{\mathrm{a}}$ & $8.1 \pm 0.87^{\mathrm{a}}$ & $8.1 \pm 0.99^{\mathrm{ab}}$ \\
SCO & $8.0 \pm 1.15^{\mathrm{abc}}$ & $7.7 \pm 1.25^{\mathrm{b}}$ & $7.3 \pm 1.49^{\mathrm{a}}$ & $7.5 \pm 1.26^{\mathrm{a}}$ & $7.4 \pm 1.26^{\mathrm{b}}$ \\
Kofta: & & & & & \\
KQ & $8.5 \pm 0.70^{\mathrm{ab}}$ & $7.9 \pm 0.73^{\mathrm{ab}}$ & $8.0 \pm 1.05^{\mathrm{a}}$ & $7.4 \pm 1.71^{\mathrm{a}}$ & $8.1 \pm 0.87^{\mathrm{ab}}$ \\
KC & $8.2 \pm 1.03^{\mathrm{abc}}$ & $8.0 \pm 0.94^{\mathrm{ab}}$ & $7.8 \pm 1.13^{\mathrm{a}}$ & $8.2 \pm 0.78^{\mathrm{a}}$ & $7.9 \pm 0.99^{\mathrm{ab}}$ \\
KCO & $7.6 \pm 1.34^{\mathrm{b}}$ & $7.7 \pm 1.05^{\mathrm{b}}$ & $7.6 \pm 1.64^{\mathrm{a}}$ & $7.8 \pm 1.13^{\mathrm{a}}$ & $7.5 \pm 1.43^{\mathrm{ab}}$ \\
Nuggets: & & & & & \\
NQ & $8.3 \pm 0.82^{\mathrm{abc}}$ & $8.3 \pm 0.67^{\mathrm{ab}}$ & $7.8 \pm 1.03^{\mathrm{a}}$ & $7.5 \pm 1.43^{\mathrm{a}}$ & $8.1 \pm 0.73^{\mathrm{ab}}$ \\
NC & $7.8 \pm 0.78^{\mathrm{abc}}$ & $7.7 \pm 0.94^{\mathrm{b}}$ & $7.4 \pm 1.07^{\mathrm{a}}$ & $7.5 \pm 0.70^{\mathrm{a}}$ & $7.7 \pm 0.67^{\mathrm{ab}}$ \\
NCO & $8.7 \pm 0.67^{\mathrm{a}}$ & $8.8 \pm 0.63^{\mathrm{a}}$ & $8.4 \pm 1.07^{\mathrm{a}}$ & $8.4 \pm 1.34^{\mathrm{a}}$ & $8.5 \pm 1.08^{\mathrm{a}}$ \\
\hline
\end{tabular}

SQ----> sausage from quail meat, SC-----> sausage from chicken meat as control, SCo---->sausage commercial. KQ-----> kofta quail meat Kofta from chicken meat as control, KCo-----> kofta commercial. NQ-----> nuggets from quail, NC-----> nuggets from chicken meat as control, NCo-----> nuggets commercial. 


\section{Conclusion}

Results of this study which confirmed the successful use of quail meat in producing healthier products were high in protein, minerals and vitamins content; and improving physical and sensory properties.

\section{Conflicts of Interest}

The authors declare no conflicts of interest regarding the publication of this paper.

\section{References}

[1] Cunha, R.G.T. (2009) Quail Meat-An Undiscovered Alternative. World Poultry, 25, 12-14.

http://www.worldpoultry.net/Other-Poultry-Species/Other-Poultry-Species/2009/2/ Quail-meat-an-undiscovered-alternative-WP006930W/

[2] Santos, T.C. and Murakami, A.L. (2011) Production and Reproduction of Egg- and Meat Type Quails Reared in Different Group Sizes. Brazilian Journal of Poultry Science, 13, 9-14. https://doi.org/10.1590/S1516-635X2011000100002

[3] Alarslan, O.F. (2006) Modern Quail Manufacturing and Basic Nutrition Principles.

[4] Mountney, G.J. (1976) Poultry Products Technology. 2nd Edition, AVI Publishing Company, Westport.

[5] La Neve, F., Civera, T., Mucci, N. and Bottero, M.T. (2008) Authentication of Meat from Game and Domestic Species by SNaPshot Minisequencing Analysis. Meat Science, 76, 216-224. https://doi.org/10.1016/j.meatsci.2007.11.027

[6] Mielnik, M.B., Aaby, K., Rolfen, K., Ellekjaer, M. and Nilsson, A. (2001) Quality of Comminuted Sausage Formulated from Mechanically Deboned Poultry Meat. Meat Science, 61, 73-84. https://doi.org/10.1016/S0309-1740(01)00167-X

[7] Bayomy, H.M., Rozan, M.A. and Mohammed, G.M. (2017) Nutritional Composition of Quail Meatballs and Quail Pickled Eggs. Journal of Nutrition \& Food Sciences, 7, Article No. 584.

[8] Ikhlas, B., Huda, N. and Noryati, I (2011) Chemical Composition and Physicochemical Properties of Meatballs Prepared from Mechanically Deboned Quail Meat Using Various Types of Flour. International Journal of Poultry Science, 10, 30-37. https://doi.org/10.3923/ijps.2011.30.37

[9] Wen, Z.G., Du, Y.K., Xie, M., Li, X.M., Wang, J.D. and Yang, P.L. (2017) Effects of Low-Protein Diets on Growth Performance and Carcass Yields of Growing French Meat Quails (France Coturnix Coturnix). Poultry Science, 96, 1364-1369. https://doi.org/10.3382/ps/pew321

[10] Grieser, D.O., Marcato, S.M., Ferreira, M.F.Z., Oliveira-Bruxel, T.M., Zancanela, V., Ferreira, M.S., Stanquevis, C.E. and Finco, E.M. (2017) Productive Performance, Body Chemical Composition, and Deposition of 42-Day-Old Quail for Meat Subjectedto Quantitative Dietary Restriction. Semina: Ciências Agrárias 38, 855-866. https://doi.org/10.5433/1679-0359.2017v38n2p855

[11] de Paulo Farrapo, S., Alves, M.G.M., de Carvalho Brito, J., Batista, A.S.M., Freitas, E.R. and Nascimento, G.A.J. (2017) Animal Performance, Yield and Characteristics of the Meat of Quail Fed Diets Containing Vegetable and Mixed Glycerine. Pesquisa Agropecuária Brasileira, 52, 768-775.

https://doi.org/10.1590/S0100-204X2017000900009 
[12] Goodson, J., Beckstead, R.B. and Payne, J. (2015) Amino Acid Sequence of Japanese Quail (Coturnix japonica) and Northern Bobwhite (Colinus virginianus) Myoglobin. Food Chemistry, 181, 256-262. https://doi.org/10.1016/j.foodchem.2015.02.091

[13] Figueiredo, S., Livio, F. and Coimbra, F. (2019) Analyzing the Chemical Composition and Quality of Meat. Revisit Scientific-Faulted Decencies Veterinaries, 29, 264-267.

[14] Resurreccion, A.V. (2003) Sensory Aspects of Consumer Choose for Meat and Meat Products. Meat Science, 66, 11-20. https://doi.org/10.1016/S0309-1740(03)00021-4

[15] Mandigo, R.W. (1986) Restructuring of Muscle Foods. Food Technology, 40, 85-89.

[16] AOAC (Association of Official Analytical Chemists) (2000) Official Methods of Analysis. 17th Edition, Association of Official Analytical Chemists, Gaithersburg.

[17] AMSA (American Medical Student Association) (1995) Research Guide Line for Cookery. Sensory Evaluation and Instrumental Tenderness Measurements of Beef. American Medical Student Association, Chicago.

[18] Soloviev, V.E. (1966) Meat Aging. Food Industry Publishing, Moscow, 53-81. (In Russia)

[19] Tsolaze, E.A. (1972) The Relationship between the Tenderness of Fish Meat and Its Protein-Water \& Protein-Water Fat Coefficients. Fish Industry, 48, 68-69.

[20] Watts, B.M., Yamaki, G.L., Jeffery, L.E. and Elias, L.G. (1989) Basic Sensory Methods for Food Evaluation. 1st Edition, The International Development Research Center Publishing, Ottawa.

[21] Glinkina, I.M., Kashirina, N.A. and Ponomareva, I.N. (2020) Qualitative Analysis of Quail Meat of Various Genotypes. IOP Conference Series. Earth and Environmental Science, 422, Article ID: 012063. https://doi.org/10.1088/1755-1315/422/1/012063

[22] Lister, D. (1996) The Meat We Eat: Notions of Quality for Today or Tomorrow. 2. The Appeal and Organoleptic Properties of Meat. Outlook on Agricriculture, 25, 263-266. https://doi.org/10.1177\%2F003072709602500409

[23] Hughes, E., Cofrades, S. and Troy, D.J. (1997) Effect of Fat Level, Oat Fiber and Carrageenan on Frankfurters Formulated with 5, 12 and 30\% Fat. Meat Science, 45, 273-281. https://doi.org/10.1016/S0309-1740(96)00109-X 